\title{
THE IMPACT OF SHOPPING MALL DEVELOPMENT ON SMALL TOWNSHIP RETAILERS
}

\author{
AA Ligthelm \\ Bureau of Market Research, University of South Africa
}

\begin{abstract}
The retail sector forms a critical element of a community's economic and social welfare. It provides people with choices and services. These choices were until recently very limited in township areas. The pre-1994 retail landscape was dominated by small, often informal businesses offering basic household necessities to relatively low income earners. This has resulted in township residents' preference to shop outside townships, known as 'outshopping'.

Rapid income growth of township residents since 1994 resulted in a substantial increase in consumer expenditure in these areas, known as 'in-bound shopping'. This lucrative emerging market forms the last retail frontier in South Africa and is being explored by national retailers, especially supermarket chains. This article is aimed at establishing the impact of shopping mall development in townships on the traditional small township retailers including spaza/tuck shops.

The net balance sheet on the impact of shopping mall development on small township retailers clearly suggests a decline in the township retailers' market share. A change in small business model towards, inter alia, effective customer service with a small dedicated assortment of merchandise, satisfaction of emergency needs, selling in small units and extension of credit facilities may result in the survival of some small township retailers (albeit often at a smaller turnover).
\end{abstract}

JEL L81

\section{1}

\section{Introduction}

The past thirty years have seen widespread decentralisation of retail space throughout the large metropolitan areas to suburban areas. In most metropolitan areas, this trend resulted in a decline of the central city areas. Until recently, this new structuring of retail space largely excluded the development of township areas. In the municipal area of Johannesburg in 2004, for example, Soweto contained an estimated 43 per cent of Johannesburg's population but only approximately 3 per cent of the city's retail floor spaces (City of Johannesburg, 2005: 20).

The pre-1994 retail landscape in the township areas was dominated by small, mainly informal retail businesses offering basic products and services to a relatively low income consumer market. These businesses served as convenience shops to primarily lower income groups and attracted only a small portion of the consumer spending in township areas. The majority of township workers engaged in economic activities outside the townships with most of their shopping being in the main city centres or at shopping malls at the fringes of township areas.

Since the late 1990s township inhabitants have experienced a substantial economic uplift. Many township consumers have progressed to a middleincome group resulting in a significant increase in the consumer spending of the inhabitants of these areas. This increase in spending, together with the fact that many traditional retailing areas are becoming saturated, has caused national retailers, especially supermarket chains, to increasingly focus on market expansion strategies in these emerging markets (Tagg, 2006; Tustin \& Strydom, 2006). This increasing movement of formal retailers into previously untapped middle- and low-income markets 
has resulted in an increase in shopping centre development in townships.

\section{2}

\section{Objectives}

The article is aimed at analysing the impact of shopping mall development on the survival of small informal and formal retailers located in township areas. Focus will be placed on the sustainability of both informal spaza/tuck shops and small township retailers ${ }^{1}$ that operate in direct competition with the newly established national retailers and franchises.

The article also explores the importance of retail development to improve consumer choices, the structure of the retail environment in South Africa and consumer income growth prior to conducting inferential analysis of shopping mall development on small township retailers.

\section{3}

\section{Expanding consumer choices}

Retail intermediaries are a vital link in the distribution channel ranging from the producer/ manufacturer through the wholesaler and retailer to the final consumer. Retailing is defined by Levy and Weitz (2007: 7) as the set of business activities that adds value to the products and services sold to consumers for their personal or family use. Retailers are the final business in a distribution channel that links manufacturers to consumers. The value-creating functions of retailers are the following:

- Providing an assortment of products and services. Supermarkets, for example, stock thousands of products allowing customers to choose from a wide variety of brands, designs, colours, prices, etc. at one location.

- Breaking bulk. It is cost effective for manufacturers to package and transport goods in bulk while consumers demand goods in smaller quantities.

- Keeping an inventory allowing consumers to purchase products when the need arises. This allows households to keep small inventories at home.
- Providing various services to customers that make the buying decision far easier and more informed. Examples of services are purchases on credit, product information and display of merchandise allowing visual contact and even testing.

Retailers range from small informal street vendors to large multi-national chain stores selling goods and/or services to final consumers (Lewison, 1997; McGoldrick, 1998; Newman \& Cullen, 2003).

The retail sector forms a critical element of a community's economic and social welfare and provides people with choices of products and services. These choices were until recently, extremely limited in township areas. This was particular relevant for the lower income groups. In a 2004 survey in Soweto (City of Johannesburg, 2005: 15), it was established that the poorest households (income of less than R500 per month) spent 82 per cent of their income on retail goods and services. Of this expenditure, almost half (49 per cent) was spent within the township areas thus giving them limited consumer choice. In contrast, the most affluent households (R12 000 plus per month) spent 91 per cent of their retail expenditure outside township areas suggesting substantially more consumer choice was available for the relatively small percentage of affluent township dwellers.

The above clearly shows that the lack of an efficient retail infrastructure in a township has a far more negative impact on the poorer households in that township compared to the more affluent ones. As a result, the following township expenditure dynamics were the norm prior to the recent establishment of township shopping malls (Tustin \& Strydom, 2006; Radebe, 2005; De Vynck, 2005):

- Low car ownership and underdeveloped transport systems result in people (especially the less affluent) either walking or using taxis to go shopping within townships.

- Township dwellers often travel by taxi to shop at nearby urban retail outlets rather than in township shops.

- Purchases are limited to small quantities of groceries at a time (day-to-day buying). 
- The concept of 'shoppertainment' is not yet well developed in townships. Only residents higher up on the social and income ladders prefer to shop outside their neighbourhoods (so-called 'aspirational shopping').

- The bulk of small township retailers can be classified as survivalists who do business only to fend for themselves.

- Workers tend to do their shopping close to their places of work, these are primarily located outside townships.

- Township residents who have moved up the social and income ladders prefer to shop outside townships in upmarket shopping malls, known as 'outshopping'.

The above historical dynamics of township shopping patterns together with continued upliftment of African consumers (see next section) create an environment conducive to profitable retail development in township areas.

\section{4 \\ The emerging middle class}

South Africa has made significant strides in improving the living standards of the previously disadvantaged communities. Table 1 depicts the class dynamics of the South African adult population during 1998 to 2003 and includes projections to 2008. It is evident from Table 1 that the most significant gains in respect of improvements in social class were made during the period 1998 to 2003 with regard to the African middle class. The percentage of Africans in LSM 8-10 (i.e., the realised African middle class) increased from 2.8 per cent of the African adult population in 1998 to 10.5 per cent in 2008. In absolute terms this represents an increase from just over half a million people to an estimated 2.7 million in 2008. The share of the emerging African middle class (LSM 5-7) increased with almost 12 percentage points (or 7.2 million adults) from 52.5 per cent of adult Africans in 1998 to 65.2 per cent in 2008.

Table 1

Comparative percentage breakdown of class dynamics by population group, 1998 to 2008

\begin{tabular}{|c|c|c|c|c|}
\hline & Africans & Asians & Coloureds & Whites \\
\hline \multicolumn{5}{|c|}{1998} \\
\hline LSM 8-10 & 2.8 & 57.2 & 30.1 & 87.2 \\
\hline LSM 5-7 & 52.5 & 42.5 & 60.4 & 12.8 \\
\hline LSM 1-4 & 44.7 & 0.3 & 9.5 & 0.0 \\
\hline Total & 100.0 & 100.0 & 100.0 & 100.0 \\
\hline \multicolumn{5}{|c|}{2003} \\
\hline LSM 8-10 & 5.6 & 57.3 & 32.1 & 87.1 \\
\hline LSM 5-7 & 60.5 & 42.6 & 59.6 & 12.9 \\
\hline LSM 1-4 & 33.9 & 0.1 & 8.3 & 0.0 \\
\hline Total & 100.0 & 100.0 & 100.0 & 100.0 \\
\hline \multicolumn{5}{|c|}{2008} \\
\hline LSM 8-10 & 10.5 & 55.4 & 32.6 & 86.0 \\
\hline LSM 5-7 & 65.2 & 44.5 & 59.5 & 14.0 \\
\hline LSM 1-4 & 24.3 & 0.1 & 7.9 & 0.0 \\
\hline Total & 100.0 & 100.0 & 100.0 & 100.0 \\
\hline
\end{tabular}

1) Living Standards Measure (LSM) denotes the asset wealth of households as measured by the ownership of a range of assets and amenities. The South African LSM ranges from LSM 1 representing the poorest of the poor to LSM 10 representing the richest of the rich. Research shows that LSM 1 to 4 are households living below the bread line, LSM 5 to 7 denote the emerging middle class while LSM 8 to 10 denotes the realised middle class. 
This rapid growth in the African middle class is also reflected in the African share of the country's total personal disposable income. Figure 1 shows an increase in the African portion of the total personal disposable income from 35.7 per cent in 1990 to 46.5 per cent in 2007.

Figure 1

The population groups' shares of the total personal disposable income, 1990-2007

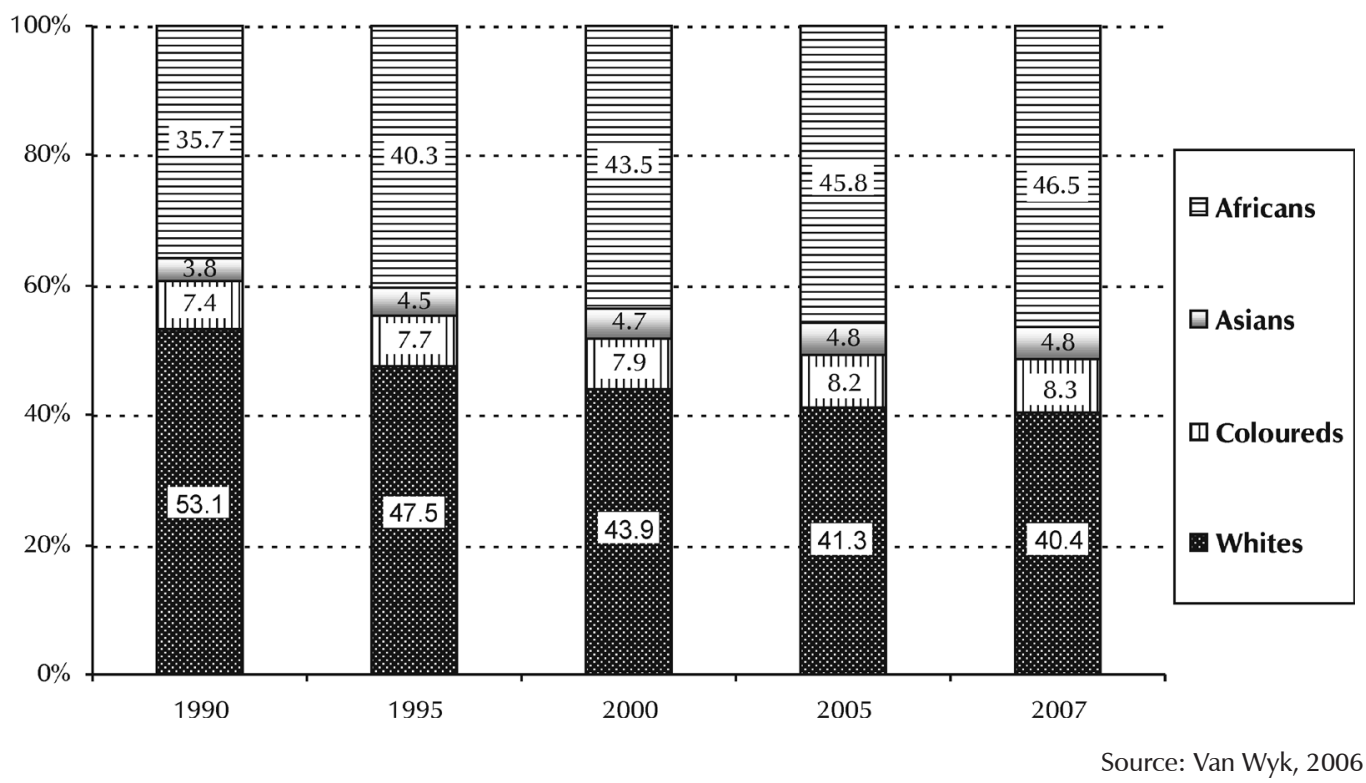

The emerging trend that can be seen in Figure 1 is a substantial growth in the income levels of the African population. The question arises, is this expansion of consumer demand also materialising in township areas, and if the answer is yes, is it sustainable in the long run?

A study embracing all the major township areas in South Africa suggests a fairly stable demographic pattern in townships (Glue Metric \& Lilanda Holdings, 2006). The study was only conducted in middle-income areas in the following townships: Soweto, Tembisa, Soshanguve, Mamelodi, KwaMashu, Mangaung and Khayelitsha. Informal (squatter) and RDP housing areas were excluded from the survey. Figure 2 shows that, according to the study, 86 per cent of all middle-income township inhabitants reside in a specific township area for more than four years. It also shows that three in every five respondents had inhabited their townships for longer than 10 years. The relatively stable middle-income demographic pattern is supported by the fact that only 2 per cent of middle-income residents had inhabited their respective areas for less than one year and only 4 per cent for between one and two years.

A question was also included in the Glue Metric and Lilanda Holdings (2006) questionnaire enquiring about how long respondents planned to live in the townships. Figure 3 shows that almost three in every four ( 72 per cent) of middle-income earners in township areas either plan to live there for some time (29 per cent) or regard the township area as their home without having any intention of moving (43 per cent). A little over a quarter ( 28 per cent) indicated that they wanted to move as soon as possible, to live in the suburbs (17 per cent), to move to a different suburb (8 per cent), or to live in a rural area ( 3 per cent).

These findings suggest a fairly stable middleincome population base in township areas that may further increase as more people progress into the middle-income group. The gravitation of a relatively small percentage of township residents to suburbs will probably be countered 
by further growth in the number of middleincome township dwellers as well as income growth within the existing middle-income group. If appropriate retail choices and services are available in township areas, it can be expected that the upsurge in consumer spending in townships will be sustainable, at least for the foreseeable future.

\section{Figure 2}

Period of residence in the major township areas of South Africa

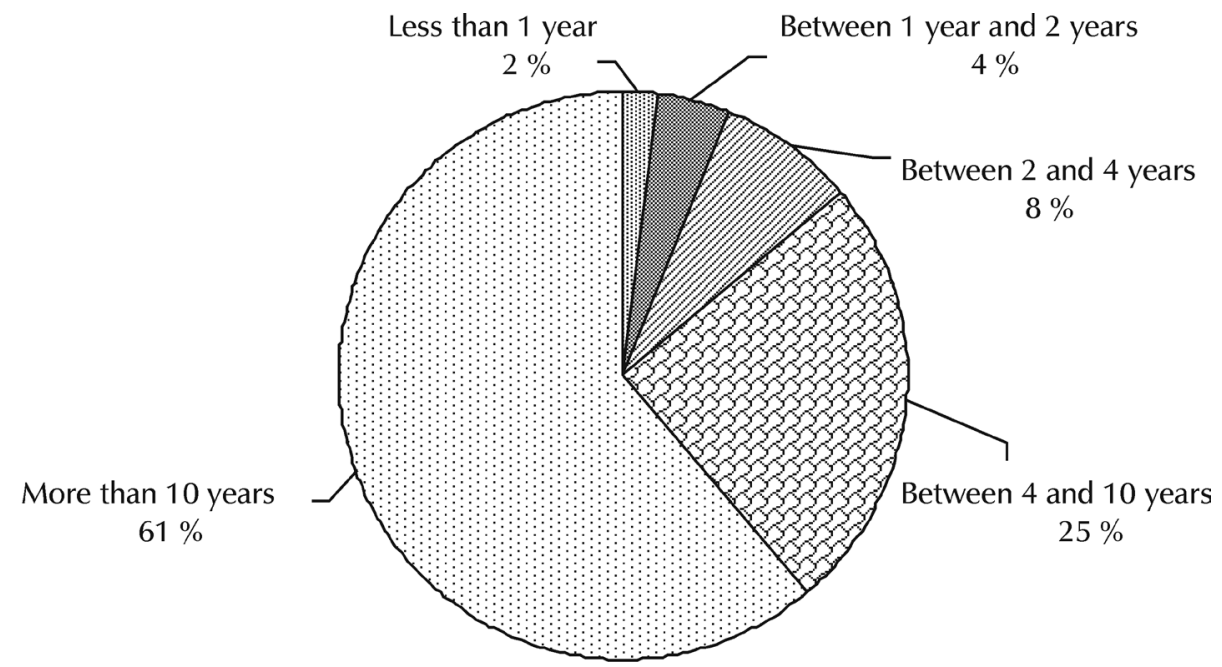

Source: Glue Metric \& Lilanda Holdings, 2006

Figure 3

Intended stay in township area

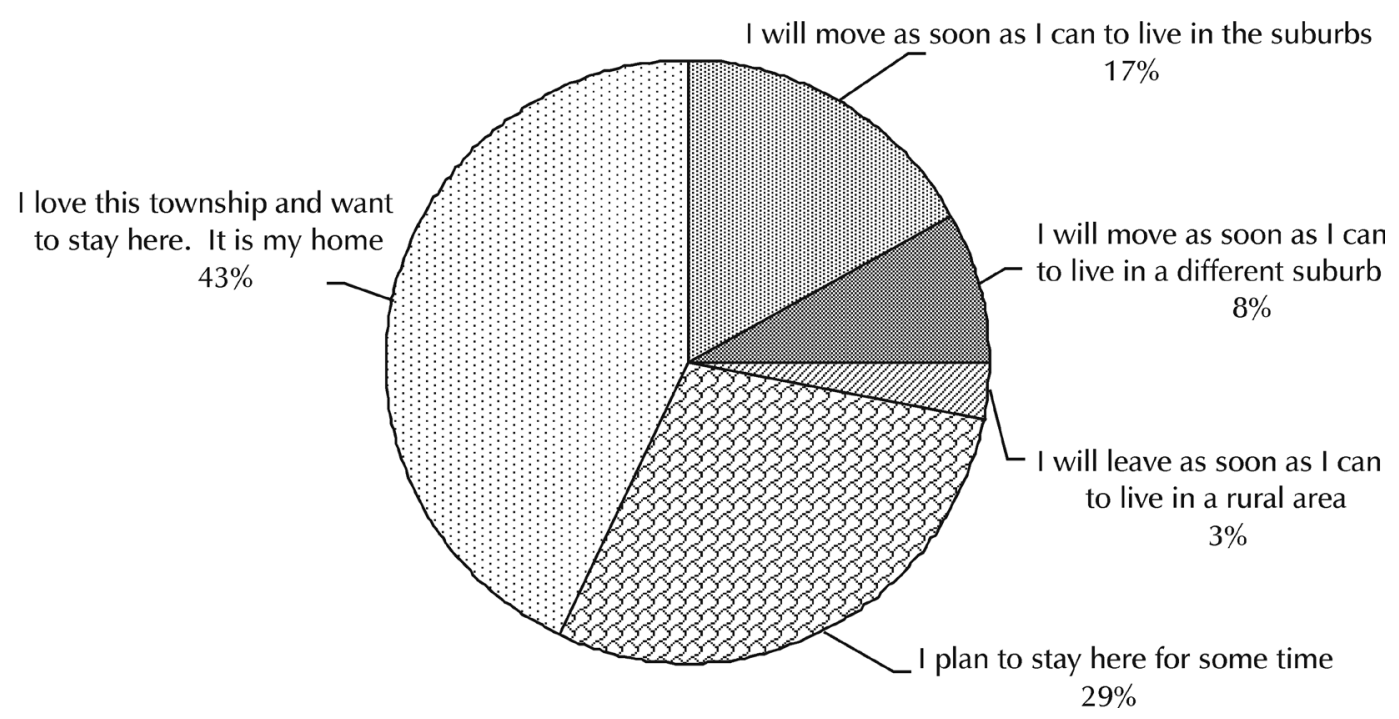

Source: Glue Metric \& Lilanda Holdings, 2006 
5

\section{Shopping mall development in townships}

Since the turn of the century townships have emerged as the new market for national retailers. The increasing movement of grocery chains into previously untapped markets has resulted in a substantial increase in shopping mall development in townships. Most large shopping mall developments are anchored by national grocery chains offering a wide variety of food and grocery products not previously offered in township areas. The national grocery chains have already asserted their dominance in the formal grocery and food market. At the end of 2005, the three largest groups already commanded just over 90 per cent of the national formal grocery and food market (Tustin \& Strydom, 2006: 54).

The national grocery chains will offer products that are similar to some offered by small township retailers; this will undoubtedly lead to increased competition. Whether small, often informal, sector survivalists will survive this competition from national retail chains is analysed in section 7 of this article.

The South African Council of Shopping Centres does not unfortunately maintain a list of newly developed shopping centres in townships. Extracts from the financial press (see detailed press sources in Tustin \& Strydom, 2006 and Ligthelm \& Risenga, 2006) include the following township areas where shopping mall investment has occurred or is planned (see Table 2).

Table 2

Shopping mall development in township areas

\begin{tabular}{|c|c|c|c|c|c|}
\hline \multirow[t]{2}{*}{ Province } & \multirow[t]{2}{*}{ Shopping mall } & \multirow[t]{2}{*}{ Location } & \multirow[t]{2}{*}{ Area } & \multicolumn{2}{|c|}{ Size } \\
\hline & & & & $\begin{array}{l}\text { Rand } \\
\text { (million) }\end{array}$ & Sq metre \\
\hline \multirow[t]{6}{*}{ Gauteng } & Maponya & Soweto & Johannesburg & 500 & 65000 \\
\hline & Jabulani & Soweto & Johannesburg & 250 & 30000 \\
\hline & Protea Gardens & Soweto & Johannesburg & 146 & 25000 \\
\hline & Bara Mall & Soweto & Johannesburg & 420 & 57000 \\
\hline & Diepkloof Plaza & Soweto & Johannesburg & 60 & 15000 \\
\hline & Soshanguve & Soshanguve & Pretoria & - & - \\
\hline \multirow[t]{3}{*}{ Eastern Cape } & Mdantsane & Mdantsane & East London & 100 & - \\
\hline & New Brighton Plaza & New Brighton & Port Elizabeth & 15 & 3625 \\
\hline & $\begin{array}{l}\text { Motherwell Shopping } \\
\text { Complex }\end{array}$ & Motherwell & Port Elizabeth & 32 & - \\
\hline KwaZulu-Natal & Umlazi Mega City & Umlazi & Durban & 150 & 28000 \\
\hline Limpopo & Masingita & Giyani & Giyani & 50 & 10190 \\
\hline Western Cape & Promenade & Mitchells Plain & Cape Town & 400 & 42000 \\
\hline Mpumalanga & KaNyamazane & KaNyamazane & Nelspruit & 80 & 14000 \\
\hline North West & The Crossing & Mafikeng & Mafikeng & 140 & 18500 \\
\hline
\end{tabular}

Source: eProp Commercial Property South Africa 2004-2007 (see articles cited in the references). Ligthelm \& Risenga, 2006; Tustin \& Strydom, 2006. 


\section{6}

\section{Methodology}

\subsection{Survey}

In order to fully understand the impact of chain store expansion in emerging markets, a sample of small informal and formal township retailers located in Soshanguve were interviewed. The study area, including the neighbouring areas of Mabopane, Garankuwa and Temba, accommodated almost 700000 people in 2001. The socioeconomic status of the survey area's population is representative of all the groups typical of township areas, from the low-income to middle- and higher-income groups. The average annual household income amounted to approximately R53 800 in 2006 (Municipal Demarcation Board, 2006).

The business environment of the study area consists primarily of informal homebased (spaza/tuck shops) and small township retailers typical of the pre-1994 retail township environment. Two adjacent shopping malls were opened in Soshanguve in March 2006 and house more than 70 shops representative of all the major franchises and national grocery chain stores. These include, inter alia, food and grocery retailers, furniture and clothing stores as well as fast food outlets, banks, music shops and electronic stores.

In October 2006, six months after the opening of the shopping malls, interviews were conducted with small retailers and spaza/tuck shop owners. The sampling allowed for the selection of respondent businesses in concentric circles around the new shopping malls. Figure 4 confirms that five distance categories of 1 kilometre (or 15 minutes walking time) each were selected. The various residential blocks included in each of these distance categories were selected by using the 'distance measure' on a map created by Corporate Dataware of the City of Tshwane (2006). This approach allows a measurement of the impact of shopping mall development on small retailers by distance from the malls.

Figure 4

Sampling plan

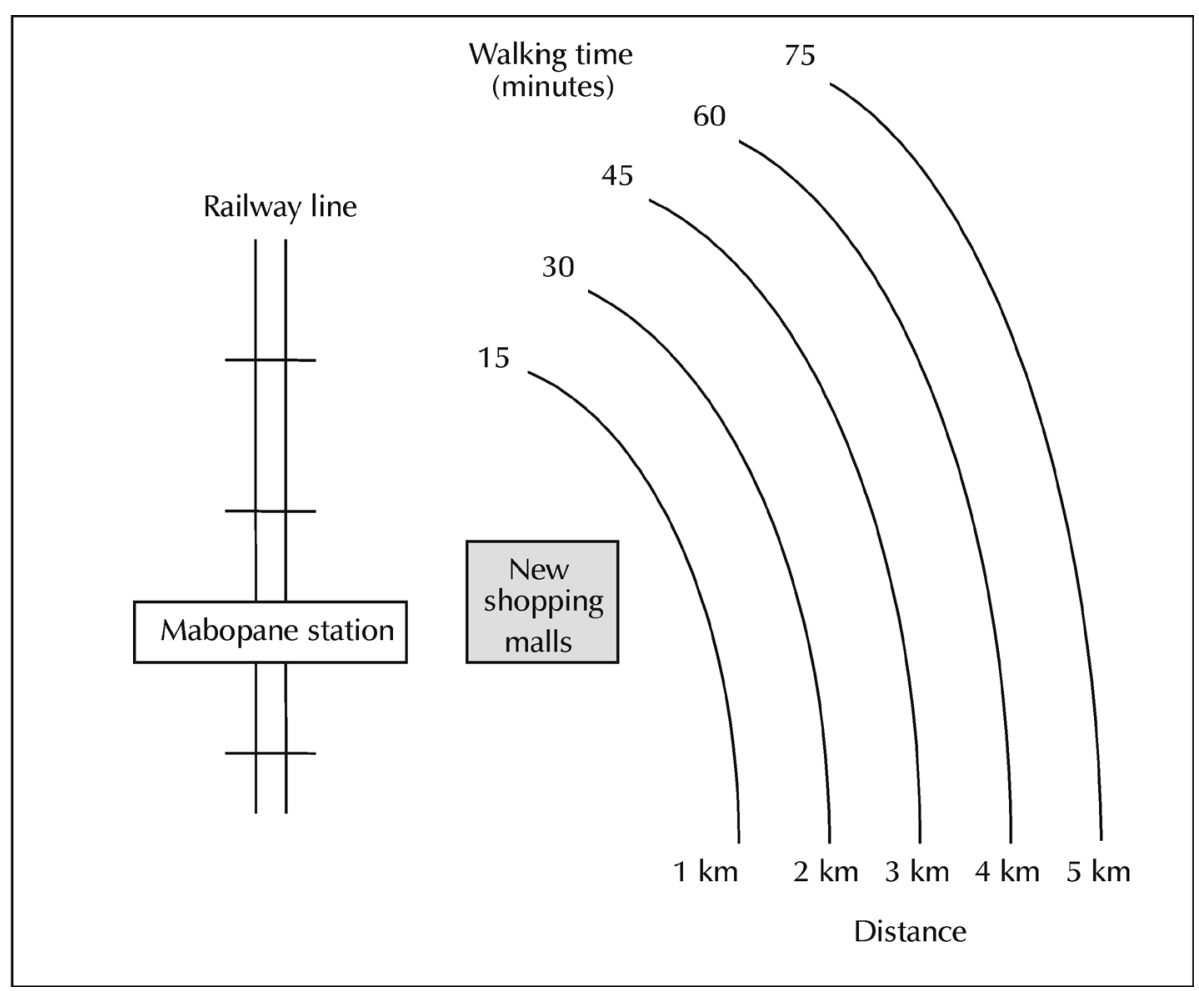


Due to a lack of a small business sample frame, a judgmental sampling procedure with quotas within each distance category was applied. A total of 100 small informal and formal businesses were interviewed across the five distance categories. The concentric circles were grouped into two categories for analysis purposes.

\subsection{Limitations}

The selection of only 20 small businesses per distance category from the shopping malls was governed by the number of small retailers within some of the 1 kilometre wide concentric circles. The methodological limitation of a small sample was addressed by validating the findings of the Soshanguve survey with the findings of previous surveys with regard to variables such as age composition of businesses, average employment size and business access to infrastructure (Table 3). Strong similarities were evident confirming that the results of the Soshanguve survey may be used as useful estimates in analysing the impact of shopping mall development on small informal and formal township retailers.

Table 3

Validation of the 2006 Soshanguve survey with comparable secondary data sources

\begin{tabular}{|c|c|c|c|c|}
\hline Variable & Soshanguve & $\begin{array}{c}\text { Gauteng } \\
\text { Eastern Cape } \\
\text { KwaZulu Natal } \\
\text { Mpumalanga } \\
\text { Western Cape }\end{array}$ & $\begin{array}{l}9 \text { provinces } \\
\text { in South Africa }\end{array}$ & $\begin{array}{l}11 \text { areas } \\
\text { in Tshwane }\end{array}$ \\
\hline Sample population & $\begin{array}{l}\text { Small township } \\
\text { retailers } \\
\text { Spaza/tuck } \\
\text { shops }\end{array}$ & $\begin{array}{l}\text { Spaza/tuck } \\
\text { shops }\end{array}$ & $\begin{array}{l}\text { Spaza/tuck } \\
\text { shops }\end{array}$ & SMEs \\
\hline Year & 2006 & 2003 & 2002 & 2001 \\
\hline Sample size & 100 & 560 & 900 & 550 \\
\hline $\begin{array}{l}\text { Age of business: } \\
\text { More than } 5 \text { years }(\%) \\
\text { Less than } 1 \text { year }(\%)\end{array}$ & $\begin{array}{c}94.0 \\
6.0\end{array}$ & $\begin{array}{l}86.4 \\
13.6\end{array}$ & $\begin{array}{l}89.4 \\
10.6\end{array}$ & $\begin{array}{l}80.1 \\
19.2\end{array}$ \\
\hline $\begin{aligned} \text { Access to: } & \text { Water (\%) } \\
& \text { Electricity (\%) }\end{aligned}$ & $\begin{array}{l}89.0 \\
98.0\end{array}$ & $\begin{array}{l}85.9 \\
97.5\end{array}$ & - & $\begin{array}{l}79.1 \\
78.9\end{array}$ \\
\hline Average employment size & 2.81 & 1.61 & - & - \\
\hline $\begin{array}{c}\text { Method to acquire merchandise: } \\
\text { Personal visit (\%) }\end{array}$ & 80.8 & 83.4 & 77.1 & - \\
\hline $\begin{array}{l}\text { Equipment in shop: } \\
\text { Refrigerator (\%) } \\
\text { Cash register (\%) }\end{array}$ & $\begin{array}{l}77.0 \\
22.0\end{array}$ & $\begin{array}{l}82.6 \\
19.0\end{array}$ & - & - \\
\hline Education level of owner: (\%) & $\begin{array}{l}\text { (Grade } 7 \text { plus) } \\
\quad 80.8\end{array}$ & $\begin{array}{l}\text { (Gr } 8 \text { plus) } \\
69.5\end{array}$ & - & - \\
\hline
\end{tabular}


It would, however, be advisable to replicate this study within twelve months with the same sample to establish the stability of the findings as reported in this article. It would also be advisable to conduct a similar study in an alternative township area such as Soweto as that may portray a somewhat different socioeconomic structure with regard to variables such as the levels of income and employment. Such a study should preferably also include other economic sectors in addition to the retail sector addressed in this article. This may assist in establishing the representativeness of the Soshanguve survey findings for wider application in South Africa.

\section{7}

\section{Survey findings}

Respondent businesses were asked several questions on the impact of the new shopping malls on the surrounding small retailers. These questions ranged from perceived small business mortalities to more exact questions on the decrease or increase in turnover, profitability, stock movement and product range of existing individual businesses.

Descriptive statistics confirm a generally negative impact of the shopping malls on the surrounding small informal and formal township retailers. Table 4 shows that almost half the respondents (47.0 per cent) reported a decline in the number of small businesses in their immediate vicinity during the six month's existence of the shopping malls. The table also shows that almost three in every five small business retailers experienced a decline in their businesses' profitability, turnover, stock movement and product range. Only a small minority reported better business conditions (between 1 per cent and 4 per cent of respondents).

Table 4

Percentage of businesses that reported a decline of business activities since the opening of the malls by type of activity

\begin{tabular}{|l|c|c|c|c|}
\hline \multicolumn{1}{|c|}{ Decline in: } & $\begin{array}{c}\text { Decrease } \\
\text { \% }\end{array}$ & $\begin{array}{c}\text { Unchanged } \\
\%\end{array}$ & $\begin{array}{c}\text { Increase } \\
\%\end{array}$ & $\begin{array}{c}\text { Total } \\
\%\end{array}$ \\
\hline Number of small retailers & 47.0 & 42.2 & 10.8 & 100.0 \\
\hline Activities within shops: & & & & 100.0 \\
\hline - Turnover & 66.0 & 30.0 & 4.0 & 100.0 \\
\hline - Profitability & 61.0 & 36.0 & 3.0 & 100.0 \\
\hline - Stock movement & 57.0 & 42.0 & 1.0 & 100.0 \\
\hline - $\quad$ Product range & 59.0 & 39.0 & 2.0 & \\
\hline
\end{tabular}

The rest of the discussion analyses the effect of the retailers distance from the malls as a discriminatory factor on their relative performance as well as other possible factors that may enhance the survival of small businesses amidst direct competition from national retailers.

\subsection{Distance from the malls}

Respondents were divided into two distance categories, namely, those closer than 2 kilometres (or less than 30 minutes walk) and those between 2 to 5 kilometres (between 30 and 60 minutes walk) from the new shopping malls. The following variables were used to determine the difference between the mean scores of the two distance categories:

- The change in the number of shops in the immediate vicinity of the respondents (a distinction is made between spaza/tuck shops and small township retailers).

- The impact on the respondent's business regarding its product range, profitability, turnover and stock size since the opening of the malls. 
- An average survival score calculated as the average score of the product range, profitability, turnover and stock size.

- The average perceived competition posed by businesses in the shopping malls.

Independent $t$-tests were conducted to compare the group means using distance from the shopping malls as the independent variable and the variables mentioned above as dependent variables.
The normality assumptions for the dependent variables were examined using the KolmogorovSmirnov test and Shapiro-Wilk statistic. The results show that the scores for the dependent variables deviate significantly from normality. It was therefore decided to do both parametric and non-parametric comparisons of the groups to verify the results.

Table 5 shows the group statistics for all the dependent variables by the two distance categories from the shopping malls.

\section{Table 5}

Group statistic of the dependent variables by distance from the malls

\begin{tabular}{|c|c|c|c|c|c|}
\hline Dependent variable & $\begin{array}{l}\text { Distance from } \\
\text { shopping malls }\end{array}$ & $\mathbf{N}$ & Mean') & $\begin{array}{c}\text { Std } \\
\text { deviation }\end{array}$ & $\begin{array}{l}\text { Std error } \\
\text { mean }\end{array}$ \\
\hline \multirow{2}{*}{$\begin{array}{l}\text { (a) Change in number of spaza } \\
\text { shops }\end{array}$} & $<2 \mathrm{~km}$ & 40 & 1.50 & .641 & .101 \\
\hline & $2-5 \mathrm{~km}$ & 58 & 1.40 & .493 & .065 \\
\hline \multirow{2}{*}{$\begin{array}{l}\text { (b) Change in number of retail } \\
\text { shops }\end{array}$} & $<2 \mathrm{~km}$ & 25 & 1.68 & .557 & .111 \\
\hline & $2-5 \mathrm{~km}$ & 43 & 2.07 & .768 & .117 \\
\hline \multirow[t]{2}{*}{ (c) Effect on product range } & $<2 \mathrm{~km}$ & 41 & 1.37 & .536 & .084 \\
\hline & $2-5 \mathrm{~km}$ & 59 & 1.47 & .537 & .070 \\
\hline \multirow[t]{2}{*}{ (d) Effect on profitability } & $<2 \mathrm{~km}$ & 41 & 1.37 & .581 & .091 \\
\hline & $2-5 \mathrm{~km}$ & 59 & 1.46 & .536 & .070 \\
\hline \multirow[t]{2}{*}{ (e) Effect on turnover } & $<2 \mathrm{~km}$ & 41 & 1.29 & .559 & .087 \\
\hline & $2-5 \mathrm{~km}$ & 59 & 1.44 & .565 & .074 \\
\hline \multirow[t]{2}{*}{ (f) Effect on stock size } & $<2 \mathrm{~km}$ & 41 & 1.34 & .530 & .083 \\
\hline & $2-5 \mathrm{~km}$ & 59 & 1.51 & .504 & .066 \\
\hline \multirow[t]{2}{*}{ (g) Average survival score } & $<2 \mathrm{~km}$ & 41 & 1.34 & .493 & .077 \\
\hline & $2-5 \mathrm{~km}$ & 59 & 1.47 & .480 & .063 \\
\hline \multirow{2}{*}{$\begin{array}{l}\text { (h) Average perceived threat from } \\
\text { businesses in shopping malls }\end{array}$} & $<2 \mathrm{~km}$ & 41 & $3.67^{2)}$ & .780 & .122 \\
\hline & $2-5 \mathrm{~km}$ & 57 & 3.97 & .497 & .066 \\
\hline
\end{tabular}

1) Scale value used for dependent variables (a)-(g): $1=$ decreased; $2=$ remained the same; $3=$ increased

2) Scale values used for dependent variable (h): $1=$ strongly disagree; $2=$ disagree; $3=$ neutral; $4=$ agree; $5=$ strongly agree

Table 6 shows the result of the Levene's test for equality of variance to determine the appropriate $t$-statistic for comparing the score means for businesses within the two distance categories as well as the result of the $t$-test for equality of means. 
Table 6

Independent samples t-test for distance from the shopping malls

\begin{tabular}{|c|c|c|c|c|c|c|c|c|c|}
\hline \multirow{2}{*}{\multicolumn{2}{|c|}{ Variables }} & \multicolumn{2}{|c|}{$\begin{array}{l}\text { Levene's test } \\
\text { for equality of } \\
\text { variance }\end{array}$} & \multicolumn{6}{|c|}{$t$-test for equality of means } \\
\hline & & $\mathbf{F}$ & Sig. & $t$ & df & $\begin{array}{l}\text { Sig. (2- } \\
\text { tailed) }\end{array}$ & $\begin{array}{l}\text { Mean } \\
\text { differ- } \\
\text { ence }\end{array}$ & $\begin{array}{l}\text { Std. error } \\
\text { difference }\end{array}$ & $\begin{array}{c}\text { Effect } \\
\text { size }\end{array}$ \\
\hline $\begin{array}{l}\text { Change in } \\
\text { number of } \\
\text { spaza shops }\end{array}$ & $\begin{array}{l}\text { Equal } \\
\text { variances } \\
\text { not assumed }\end{array}$ & 6.269 & .014 & .860 & 69.495 & .393 & .103 & .120 & 0.008 \\
\hline $\begin{array}{l}\text { Change in } \\
\text { number of } \\
\text { retail shops }\end{array}$ & $\begin{array}{l}\text { Equal } \\
\text { variances } \\
\text { assumed }\end{array}$ & 1.345 & .250 & -2.218 & 66 & .030 & -.390 & .176 & 0.069 \\
\hline $\begin{array}{l}\text { Effect on } \\
\text { product } \\
\text { range }\end{array}$ & $\begin{array}{l}\text { Equal } \\
\text { variances } \\
\text { assumed }\end{array}$ & .838 & .362 & -.996 & 98 & .322 & -.109 & .109 & 0.010 \\
\hline $\begin{array}{l}\text { Effect on } \\
\text { profita- } \\
\text { bility }\end{array}$ & $\begin{array}{l}\text { Equal } \\
\text { variances } \\
\text { not assumed }\end{array}$ & .079 & .779 & -.814 & 98 & .418 & -.092 & .113 & 0.007 \\
\hline $\begin{array}{l}\text { Effect on } \\
\text { turnover }\end{array}$ & $\begin{array}{l}\text { Equal } \\
\text { variances } \\
\text { assumed }\end{array}$ & 2.222 & .139 & -1.294 & 98 & .199 & -.148 & .114 & 0.017 \\
\hline $\begin{array}{l}\text { Effect on } \\
\text { stock size }\end{array}$ & $\begin{array}{l}\text { Equal } \\
\text { variances } \\
\text { assumed }\end{array}$ & 1.152 & .286 & -1.596 & 98 & .114 & -.167 & .105 & 0.025 \\
\hline $\begin{array}{l}\text { Average } \\
\text { survival } \\
\text { score }\end{array}$ & $\begin{array}{l}\text { Equal } \\
\text { variances } \\
\text { assumed }\end{array}$ & 1.761 & .188 & -1.305 & 98 & .195 & -.129 & .099 & 0.017 \\
\hline $\begin{array}{l}\text { Average } \\
\text { perceive } \\
\text { threat from } \\
\text { businesses } \\
\text { in shopping } \\
\text { malls }\end{array}$ & $\begin{array}{l}\text { Equal } \\
\text { variances } \\
\text { not assumed }\end{array}$ & 5.926 & .017 & -2.189 & 62.972 & .032 & -.303 & .138 & 0.048 \\
\hline
\end{tabular}

An analysis of Tables 5 and 6 shows that, on average, the following variables did not show a statistically significant difference between businesses that are less than 2 kilometres away from the shopping malls and those between 2 and 5 kilometres from the malls:

- change in the number of spaza/tuck shops

- product range

- profitability

- turnover
- $\quad$ product stock sizes

- average survival score

The reported change in the number of small township retailers differs significantly between those that are less than 2 kilometres $(M=1.68 S D=.557)$ away from the shopping malls and those between 2 and 5 kilometres $(M=2.07, S D=.768)$ away from the shopping malls, $t(66)=-2.218, p<.05, \eta^{2}=.069$. The effect size estimate of .069 in the last column of 
Table 6 represents, according to Cohen (1988), a moderate effect. More specifically, small retail shops that are 2 kilometres or more away from the shopping malls tended on average towards reporting either no change or an increase in the number of small township retailers in their area since the opening of the shopping malls, whereas businesses closer than 2 kilometres from the shopping malls tended on average towards observing a decrease in the number of retail shops in their immediate vicinity since the opening of the shopping malls.

The average perceived threat from businesses in the shopping malls differs significantly between small businesses that are less than 2 kilometres $(M=3.671, S=.780)$ away from the shopping malls and those between 2 and 5 kilometres $(M=3.974, S D=.497)$ away from the shopping malls, $t(62.972)=-2.189, p<.05$, $\eta^{2}=.048$. The effect size estimate represents a small to moderate effect (Cohen 1988). More specifically, the shops closer than 2 kilometres from the shopping malls feel less threatened by businesses in the shopping malls than those that are between 2 and 5 kilometres away from the shopping malls. A possible explanation for this phenomenon may be that shops closer to the malls, who were initially more exposed to competition from the malls, had already adjusted their business plans (in terms of, for instance, assortment of merchandise, price levels, customer service and stock replenishment) to continue as convenience shops for their immediate and regular customers, albeit at a lower turnover level. The respondents listed the following principal factors in ensuring continued customer support:

- friendly service

- long and flexible hours

- safe environment to buy in

- satisfy emergency needs

- allow buying on credit

- sell in small quantities

Furthermore, a larger percentage of respondents within 2 kilometres of the malls reported the closure of small retailers since the opening of the malls compared to those beyond 2 kilometres. This implies that the sample within 2 kilometres of the malls probably already excludes a larger proportion of business mortalities than those between 2 and 5 kilometres from the new malls.

From the fact that distance from the shopping malls showed no significant difference on the impact on profitability, turnover, product range and stock size of the businesses since the opening of the shopping malls, it can be concluded that all the small informal and formal retailers within 5 kilometres of the shopping malls perceived more or less the same type of negative impact on the profitability of their businesses. This conclusion is corroborated by the mean scores for the perceived effect that the opening of the shopping malls had on these four aspects of the smaller businesses. Table 5 shows mean scores of below 2 (where $1=$ decreased, $2=$ remained the same and $3=$ increased) confirming that most of the respondents experienced a decline.

In order to ascertain that the non-normality of the data did not influence the results, the Mann-Whitney $U$-test was also performed to investigate the effect that distance from the shopping malls may have on the group median scores using distance from the shopping malls as the independent variable and the variables measuring the different quantities (see 7.1 (a) to (d)), as the dependent variables. The advantage of this test is that it does not make any assumptions about the underlying distributions of the dependent variables. These tests corroborate all the findings of the independent $t$-tests with distance from the malls as the independent variable as discussed above.

\subsection{Decline in client patronage}

A question to respondents on the perceived reduction in regular client patronage was used to establish the extent to which the shopping malls development impacted differently on spaza/tuck shops compared to small township retailers. This led to the question: Is there a relationship between the type of small businesses and the perceived reduction in regular client patronage since the opening of the malls? The $2 \times 2$ Chisquare test of independence was used to test the relationship between retailers of a certain type and whether they experienced a decline (or even a termination) in their regular customers' use of their businesses. 
The results of the test indicate no significant relationship between the type of shop (spaza/ tuck shop or small township retailer) and whether they experienced a decline (or even a termination) in their regular customers' use of their businesses $\left(\chi^{2}(1, N=100)=2.850, n s\right)$.

The findings indicate that the proportion of spaza/tuck shops that experienced a decline in patronage of regular customers is not significantly different from the proportion of small township retailers that experienced a decline in patronage of regular customers.

The question to respondents on their perceived reduction in regular client patronage also allows the determination of the relationship between the proximity of small businesses to the shopping malls and perceived reduction in regular client patronage since the opening of the malls. As with the previous test, a $2 \times 2$ Chi-square test of independence was used to test the relationship between a shop's distance from the shopping malls and whether it experienced a decline (or even a termination) in its regular customers' use of the business.

The results of the test indicate no significant relationship between how far a shop is situated from the shopping malls (less than 2 kilometres or 2 to 5 kilometres away) and whether it experienced a decline (or even a termination) in its regular customers' use of the business $\left(\chi^{2}(1, N=100)=0.028, n s\right)$.

The findings indicate that the proportion of shops that are closer than 2 kilometres from the shopping malls that experienced a decline in patronage from regular customers is not significantly different from the proportion of shops that are from 2 to 5 kilometres away from the shopping malls that experienced a decline in patronage from regular customers.

\subsection{Factors responsible for survival}

The discussion in the previous two sections confirms a generally negative impact of shopping mall development on small informal and formal retailers. The question arises: Are there specific factors that can be regarded as the strongest predictors of business survival after the opening of shopping malls?

Respondents were divided into various dichotomous groups on the basis of relevant information contained in the questionnaire. Table 7 depicts the selected dichotomous groups ranging from business maturity to the educational level and age of the business owner.

Table 7

Dichotomous groups to identify predictors of survival

\begin{tabular}{|c|c|c|}
\hline Variable & Group 1 & Group 2 \\
\hline Business maturity (age of business) & Less than 5 years & 5 years and older \\
\hline How merchandise is purchased from suppliers & Own cost and effort & Use facilities of supplier \\
\hline $\begin{array}{l}\text { Use of technology in the shop (cash register, } \\
\text { computer, etc.) }\end{array}$ & Yes & No \\
\hline Approach to advertising (signage, flyers, posters) & Active & Passive \\
\hline Employees other than owner's family & Yes & No \\
\hline Highest level of education & Grade 12 or less & Tertiary education \\
\hline Age (of owner/manager) & Younger than 30 years & 30 years or older \\
\hline
\end{tabular}

The average survival score of businesses in the vicinity of the shopping mall was examined using the Kolmogorov-Smirnov test and Shapiro-Wilk statistic. The results indicated a significant deviation from normality of the average survival score for all the dichotomous groups. As a result both parametric and non-parametric comparisons of groups were made to compare the results.

Independent $t$-tests were conducted with the different group variables as independent variables and the average survival score as the dependent variable. 
Table 8 shows the group statistic for the average survival score (dependent variable).

Table 8

Group statistics for average survival score

\begin{tabular}{|l|l|l|l|l|l|}
\hline \multicolumn{1}{|c|}{ Variables } & \multicolumn{1}{|c|}{ Group } & N & Mean & $\begin{array}{c}\text { Std } \\
\text { deviation }\end{array}$ & $\begin{array}{c}\text { Std error } \\
\text { mean }\end{array}$ \\
\hline Business maturity & Less than 5 years & 52 & 1.43 & .503 & .070 \\
& 5 years or more & 48 & 1.41 & .474 & .068 \\
\hline Purchasing method & Own cost and effort & 82 & 1.43 & .495 & .055 \\
& Use supplier services & 17 & 1.37 & .477 & .116 \\
\hline Use of technology & Yes & 28 & 1.58 & .549 & .104 \\
& No & 72 & 1.35 & .449 & .530 \\
\hline Approach to advertising & Active & 44 & 1.49 & .503 & .076 \\
& Passive & 56 & 1.36 & .472 & .063 \\
\hline Non-family employees & Yes & 57 & 1.45 & .523 & .069 \\
& No & 43 & 1.37 & .438 & .067 \\
\hline Highest level of & Grade 12 or less & 79 & 1.39 & .459 & .052 \\
\hline education & Tertiary education & 21 & 1.50 & .586 & .128 \\
\hline Age & Younger than 30 years & 22 & 1.38 & .455 & .097 \\
\hline
\end{tabular}

1) Scale values used for variables: $1=$ decreased; $2=$ remained the same; $3=$ increased.

Levene's test for equality of variance was means for the average survival score. The results performed to determine the appropriate $t$ - of the test are contained in Table 9. statistic to use to compare the different group

Table 9

Independent samples t-test for average survival score per grouping variable

\begin{tabular}{|c|c|c|c|c|c|c|c|c|c|}
\hline & & $\begin{array}{r}\text { Leve } \\
\text { for ec } \\
\text { var }\end{array}$ & $\begin{array}{l}\text { test } \\
\text { ty of } \\
\text { es }\end{array}$ & & & st for eq & lity of $\mathrm{m}$ & ans & \\
\hline Groupin & variable & $\mathbf{F}$ & Sig. & $t$ & df & Sig. (2- & Mean & Std error & Effect \\
\hline $\begin{array}{l}\text { Business } \\
\text { maturity }\end{array}$ & $\begin{array}{l}\text { Equal } \\
\text { variances } \\
\text { assumed }\end{array}$ & .000 & .993 & .221 & 98 & .826 & .02163 & .09801 & 0.000 \\
\hline $\begin{array}{l}\text { Purchasing } \\
\text { method }\end{array}$ & $\begin{array}{l}\text { Equal } \\
\text { variances } \\
\text { assumed }\end{array}$ & .572 & .451 & .452 & 97 & .653 & .05918 & .13103 & 0.002 \\
\hline $\begin{array}{l}\text { Use of } \\
\text { technology }\end{array}$ & $\begin{array}{l}\text { Equal } \\
\text { variances } \\
\text { assumed }\end{array}$ & 3.683 & .058 & 2.121 & 98 & .036 & .22619 & .10666 & 0.044 \\
\hline
\end{tabular}




\begin{tabular}{|l|l|l|l|l|l|l|l|l|c|}
\hline $\begin{array}{l}\text { Approach to } \\
\text { advertising }\end{array}$ & $\begin{array}{l}\text { Equal } \\
\text { variances } \\
\text { assumed }\end{array}$ & .540 & .464 & 1.299 & 98 & .197 & .12703 & .09783 & 0.017 \\
\hline $\begin{array}{l}\text { Non-family } \\
\text { employees }\end{array}$ & $\begin{array}{l}\text { Equal } \\
\text { variances } \\
\text { not } \\
\text { assumed }\end{array}$ & 4.627 & .034 & .828 & 96.885 & .410 & .07966 & .09618 & 0.007 \\
\hline $\begin{array}{l}\text { Highest } \\
\text { level of } \\
\text { education }\end{array}$ & $\begin{array}{l}\text { Equal } \\
\text { variances } \\
\text { assumed }\end{array}$ & 2.351 & .128 & -.872 & 98 & .385 & -.10443 & .11978 & 0.008 \\
\hline Age & $\begin{array}{l}\text { Equal } \\
\text { variances } \\
\text { assumed }\end{array}$ & .996 & .321 & -.461 & 98 & .646 & -.05449 & .11810 & 0.002 \\
\hline
\end{tabular}

An analysis of Tables 8 and 9 shows that whether or not technology was used in the shop was the only predictor variable that had a statistically significant effect on the average survival score of a business.

The average survival score for businesses situated within 5 kilometres of the new shopping malls differed significantly between those that make use of technology such as cash registers, computers and/or photocopiers $(M=1.580$, $S D=.549)$ and those who do not $(M=1.354$, $\left.S D=.449), t(98)=2.121, p<.05, \eta^{2}=.044\right)$. The effect size estimate in the last column of Table 9 represents a small to moderate effect (Cohen 1988).

None of the other segmentation variables listed in Table 7 had a significant effect on the average survival score of the respondent businesses. These are:

- age of the business

- method of procuring merchandise (either at own cost or using the facilities of the supplier)

- active or passive approach to advertising

- employment of non-family members or not

- educational level of owner

- age of business owner/manager

In an effort to ascertain that the non-normality of the average survival scores of all the groups tested in Table 9 did not influence the results, the Mann-Whitney $U$-test was also performed. The results corroborate all the findings of the independent $t$-tests with the average survival score as the dependent variable except for the independent variable 'use of technology'. The independent $t$-test found that whether or not a shop utilised technology had a significant effect on the average survival score but the Mann-Whitney $U$-test found that there is no significant difference between the median scores for shops that use technology $(M d n=1.625)$ and those who do not $(M d n=1.000)$. It can therefore be concluded that making use of technology does not, on average, significantly improve a shop's chances of survival after the opening of a shopping mall in its vicinity, as was the case with all the other variables tested (see Table 9).

\section{8}

\section{Summary and conclusion}

The trend emerging from the foregoing discussion depicts a substantial growth in retail infrastructure and facilities in township areas with a concomitant expansion of retail choices. This resulted largely from the progression of many African consumers into a middle-income group. These developments at the top end of the retail market and the fact that many traditional retailing areas outside townships are becoming saturated have caused formal retailers to focus on market expansion strategies in emerging markets.

With a sustainable consumer expenditure level in townships, this question comes to the fore: What will the effect be on existing spaza/ tuck shops and small township retailers of the national chains exploring the lucrative township retail market? 
A primary factor that may lead to the cannibalisation of the existing small retail market share is the easy access to newly developed shopping complexes. For example, prior to the new shopping mall development almost 40 per cent of retail expenditure in Soweto originated from low-income households. The poorest satisfy almost 80 per cent of their retail needs within township areas at small township retailers and spaza/tuck shops (City of Johannesburg, 2005). More convenient access to large chain stores would suggest a gravitation of at least some of the low-income section's expenditure to such stores. Convenient access linked to price competitiveness and the extended shopping experience and entertainment at shopping malls would suggest a negative effect on the turnover of small township retailers and spaza/tuck shops.

The following services provided by small township retailers and spaza/tuck shops were given as reasons by respondents as contributing to their survival since the opening of the Soshanguve Malls:

- proximity to customers' dwellings

- good and friendly customer service

- long and flexible business hours

- satisfaction of emergency needs

- credit facilities

- availability of merchandise in small units

The net balance sheet on the impact of shopping mall development on small informal and formal township retailers clearly suggests a decline in the smaller retailers' market share. However, effective customer service and a small dedicated assortment of merchandise together with other services such as credit facilities and selling in small quantities may result in the survival of some of the small township retailers and spaza/ tuck shops (albeit often at a smaller turnover). The existence of more than 800 small informal businesses (mainly street vendors at Mabopane station in Soshanguve) amidst the operation of the nearby Central City Shopping Mall, and the existence of huge informal markets close to central business districts and taxi ranks/railway stations in metropolitan areas are cases in point. The latter provide services and products such as fruit and vegetables, traditional healing and medicines, cooked food and homemade clothing products. The question is: what should the product assortment, service levels and location of small township retailers and spaza/tuck shops be to compete effectively in the new retail environment in township areas?

In view of the fact that spaza/tuck shops alone employed more than 320000 people in 2004 (providing a living for more than one million people) it is imperative that further research be conducted on the structural changes in the retail environment of emerging markets (Ligthelm 2005). Research questions should include a detailed evaluation of the impact of newly developed shopping malls on small township retailers and spaza/tuck shops in a rapidly developed area such as Soweto, the adjustments to be effected by small retailers to effectively explore a niche market in terms of product assortment and customer services, and the training and advice needed by small retailers to effectively adjust to the new retail environment.

\section{Endnote}

1 Spaza/tuck shops are defined as small informal sector retail businesses operating in a section of an occupied residential home or in any other structure on a stand zoned or used for residential purposes and where people live permanently. Small township retailers are defined as stand-alone businesses with a brick and mortar superstructure often located in a demarcated business area but also located in the residential sections of townships. They carry a wider product range than spaza/tuck shops and have more fixtures and fittings often allowing self-service to clients. They employ less than 10 employees on a full- and parttime basis.

Reference to small informal/formal township retailers includes both spaza/tuck shops and small township retailers.

\section{References}

1 CITY OF JOHANNESBURG (2005) Soweto Retail Strategy 2005, Department of Finance and Economic Development: Johannesburg.

2 CITY OF TSHWANE (2006) Geographical Information System, http://www.gis.tshwane.gov.za (Accessed 9 February 2007). 
3 COHEN, J. (1988) Statistical Power Analysis for the Behavioural Sciences, Hillsdale: New York.

4 DE VYNCK, D. (2005) "Emerging black middle class flexes muscles", Business Report, 10 July.

5 EPROP COMMERCIAL PROPERTY SOUTH AFRICA (2004) "Soweto to get R250m shopping mall”, www.eprop.co.za/news/article (Accessed 7 March 2007).

6 EPROP COMMERCIAL PROPERTY SOUTH AFRICA (2005) "R80m shopping centre expected to boost township's development", www.eprop. co.za/news/article (Accessed 7 March 2007).

7 EPROP COMMERCIAL PROPERTY SOUTH AFRICA (2006) "National retailers sign-up as construction on Maponya Mall gets underway", www.eprop.co.za/news/article (Accessed 7 March 2007).

8 GLUE METRIC \& LILANDA HOLDINGS (2006) Culture Cruizzzing: My Health, Johannesburg.

9 LEVY, M. \& WEITZ, B. (2007) Retailing Management ( $3^{\text {rd }}$ ed.) McGraw Hill/Irwin: New York.

10 LEWISON, D.M. (1997) Retailing Management $\left(6^{\text {th }}\right.$ ed.) Prentice-Hall, Inc: New Jersey.

11 LIGTHELM, A.A. (2001) Small-Scale Enterprise Development in the Tshwane Metropolitan Municipality: Problems and Future Prospect, Unisa, Bureau of Market Research: Pretoria.

12 LIGTHELM, A.A. (2002) Characteristics of Spaza Retailers: Evidence from a National Survey, Unisa, Bureau of Market Research: Pretoria.

13 LIGTHELM, A.A. (2004) Informal Markets in Tshwane: Entrepreneurial Incubators or Survivalist Reservoirs? Unisa, Bureau of Market Research: Pretoria.
14 LIGTHELM, A.A. (2005) Measuring the Size of the Informal Sector in South Africa, Bureau of Market Research, Unisa: Pretoria.

15 LIGTHELM, A.A \& MASUKU, T. (2003) Size, Structure and Profile of the Informal Retail Sector in South Africa, Unisa, Bureau of Market Research: Pretoria.

16 LIGTHELM, A.A \& RISENGA, A. (2006) The Impact of Retail Development in Emerging Markets on Small Township Retailers, Bureau of Market Research, Unisa: Pretoria.

17 MCGOLDRICK, P.J. (1998) Retail Marketing, McGraw-Hill: London.

18 MUNICIPAL DEMARCATION BOARD (2006) Municipal Profiles, http://www.demarcation.org.za.

19 NEWMAN, A.J. \& CULLEN, P. (2003) Retailing: Environment \& Operations (2003 reprint) Thomson: London.

20 RADEBE, S. (2005) “Township shopping: It's not Sandton doll", Financial Mail, 28 July.

21 TAGG, G. (2006) Franchising: The Cornerstone for Shopping Centres and the Retail Industry, South African Council of Shopping Centres: Johannesburg.

22 TUSTIN, D.H. \& STRYDOM, J.W. (2006) "The potential impact of formal retail chains' expansion strategies on retail township development in South Africa", Southern African Business Review, 10(3).

23 VAN AARDT, C.J. (2005) A Class-Based Population Segmentation Model for South Africa, 1998-2008, Bureau of Market Research, Unisa: Pretoria.

24 VAN WYK, H.D.E.J. (2006) Personal Income of South Africans at National and Provincial Levels by Population Group, Income group, Life Stage and Life Plane, Bureau of Market Research, Unisa: Pretoria. 